\title{
Traduções de Hamlet no Brasil: um estudo diacrônico dos paratextos
}

\author{
Pedro Vieira e Janine Pimentel
}

\section{Introdução}

A obra de William Shakespeare é notoriamente conhecida no mundo todo. As suas peças são encenadas e adaptadas em todos os cantos do planeta, além de reinterpretadas e ressignificadas tanto no campo artístico quanto nas pesquisas acadêmicas. Tendo em vista considerável presença na cultura artística e literária universal, a tradução de suas obras se reveste de importância fundamental, uma vez que a mediação intercultural proporcionada pela prática tradutória possibilita a difusão dos textos shakespearianos para as mais diversas culturas.

Os estudos contemporâneos sobre as traduções da obra shakespeariana são principalmente permeados por uma busca pela compreensão não apenas dos processos que ocorrem no interior do texto traduzido, mas também pela forma como o sistema cultural de chegada absorve essas traduções. A relação entre obra literária e o seu contexto de produção e recepção adquire outro panorama quando se trata de texto literário transposto de uma língua/cultura para outra completamente diversa e, no caso de Shakespeare, em momento histórico completamente diverso do contexto de produção de suas peças.

No Brasil, tem-se uma extensa produção de traduções de peças shakespearianas publicadas por diversas editoras desde o início da década de trinta até os dias atuais. Cada tradução pode trazer diferentes leituras e interpretações do texto shakespeariano, constituindo-se como uma obra única em relação ao texto-fonte. Nas últimas décadas, os teóricos da tradução têm se interessado por essas diferentes leituras que uma 
determinada cultura faz de uma obra literária no momento de publicação de uma dada tradução. Para tanto, utilizam, entre outros, não só as traduções em si, mas também os paratextos dessas traduções para examinar a recepção da obra literária, como prefácios, introduções, posfácios, dentre outros.

A presente pesquisa pretende examinar, dentro de uma perspectiva diacrônica, os paratextos de onze traduções da peça Hamlet, a obra do cânone mais traduzida para o mercado editorial nacional. O corpus de traduções aqui utilizado não é exaustivo, mas inclui onze traduções, entre as quais se encontram a primeira tradução da peça publicada no Brasil e uma tradução recente de 2015 elaborada por Lawrence Flores Pereira. Procuramos analisar os variados elementos paratextuais presentes nessas onze traduções, buscando compreender os discursos que os permeiam e como estes se relacionam ao seu contexto sociohistórico de produção e recepção imediato. Acreditamos que o estudo dos paratextos das traduções permite analisar o texto traduzido sob o viés extratextual, dado que são discutidos os textos e elementos que cercam e discursam a respeito do texto traduzido. A análise de tipo diacrônico que propomos objetiva notar mudanças históricas no paradigma discursivo do paratexto ao longo das publicações. Para entendermos as características dos discursos presentes nos paratextos das traduções de Hamlet, o presente estudo se baseará em três paradigmas de pesquisa que possuem elos em comum e que apresentaremos na seção seguinte: os estudos descritivos da tradução (também conhecido como DTS); a teoria da recepção; e a teoria geral do paratexto.

\section{Pressupostos teóricos}

Os estudos descritivos da tradução, paradigma teórico que surgiu na década de setenta e contribuiu para o avanço da autonomia da área de estudos tradutórios no campo das ciências humanas, se caracteriza por dispor do texto traduzido como objeto de estudo e levar em consideração os fatores extratextuais que definem e moldam o processo tradutório e a inserção do novo texto na cultura-meta. Gideon Toury (2000), Itamar EvenZohar (2000) e André Lefevere (1992) mostraram como os elementos 
paratextuais, entre outros, apresentam características que expressam, em parte, a moldura que o sistema meta fornece à obra literária estrangeira e as diferenças em relação ao seu sistema de origem. Toury, por exemplo, elaborou o conceito de "pronunciamentos normativos" dentro de seu quadro teórico, referindo-se a textos externos à tradução que tratam sobre aspectos normativos do processo tradutório. $\mathrm{O}$ paratexto que trata sobre tradução se constitui como um exemplo típico do gênero. No conceito de sistema literário ${ }^{1}$ elaborado por Even-Zohar, esses fatores extratextuais se constituem como "fatores literários" que se correlacionam de modo dinâmico, regidos pelas "leis" do sistema a qual compõem. Desta forma, os paratextos podem ser fatores literários que constituem considerável relevância para a formação da obra literária como tal. Lefevere (1992), por sua vez, argumenta que tal sistema cultural se localiza em um ambiente orientado ideologicamente, no qual há um conjunto de discursos que disputam por interesses relevantes no interior de uma estrutura social. Entende-se, assim, que o paratexto pode apresentar elementos de como a obra traduzida se molda em determinado sistema cultural.

A teoria da recepção, por sua vez, é um paradigma da crítica literária que propõe uma reconfiguração do papel do leitor na interação entre o texto literário e o sistema receptor. As suas teses centrais, incorporadas principalmente nos escritos de teóricos alemães da Escola de Constança, como Hans Robert Jauss (1982) e Wolfgang Iser (1978), alegam que a dimensão da recepção do texto e do seu efeito determina a constituição da obra literária como tal, definindo-se como o fio mediador entre o aspecto histórico e o aspecto estético da obra, norteado pela comparação do texto literário com outras obras previamente lidas e pela mudança do horizonte de expectativas do público leitor ao longo da história da literatura. Ocupando a fronteira entre o texto e o público leitor, os paratextos e suas respectivas funções específicas contribuem para a compreensão da recepção da obra em dada cultura.

\footnotetext{
${ }^{1} \mathrm{O}$ conceito de sistema se fundamentaria na perspectiva funcionalista, o qual abrangeria uma rede de relações que governam um determinado conjunto de dados observáveis, no caso, as atividades literárias.
} 
A análise do presente estudo terá ainda como referência os postulados de Gerárd Genette a respeito do paratexto, além de pesquisas que aplicaram tais pressupostos aos estudos de tradução. De acordo com Genette (1987), os paratextos são elementos que funcionam para apresentar o texto com o qual eles se relacionam. Eles cercam e estendem o texto literário e asseguram a presença do texto no mundo, a sua recepção e seu consumo na forma de livro.

Os paratextos de literatura traduzida têm sido estudados de diversas formas e através de diferentes enfoques. Valerie Pellatt (2013) chama a atenção para o "caráter sedutor" desses elementos textuais através de ilustrações e outros componentes não verbais para sustentar as argumentações dos textos prefaciais, além de ressaltar o uso político e ideológico de tais componentes do livro numa tradução. A autora se pergunta, por exemplo, que componentes paratextuais presentes no textofonte devem ser mantidos na obra traduzida e que efeitos e funções tais componentes exercem sobre o texto central. Tahir-Gürçağlar (2011) aponta outros enfoques teóricos em relação aos paratextos, como a sua relevância metodológica para o estudo de história da tradução. Além disso, destaca que o desenvolvimento de tipologias para os paratextos possui relação intrínseca ao contexto que as obras pertencem, sendo fundamental tratar do sistema receptor em que a tradução se encontra para a elaboração deste tipo de estudo.

Outras pesquisas têm examinado as vozes dos tradutores presentes nos paratextos. Por exemplo, Marcia Martins (2015) examina o discurso dos tradutores a respeito do processo tradutório e verifica se as ideias contidas nesses discursos são postas em prática no texto traduzido. No seu estudo sobre as notas de tradução presentes em várias traduções, Carmen Toledano Buendía (2013) mostra que os elementos paratextuais servem de artifício para que a voz do tradutor seja ouvida. A pesquisadora argumenta que o estudo de notas de tradução e outros tipos de paratexto podem fornecer informações relevantes para a contextualização dos processos tradutórios bem como para entender as normas e políticas vigentes da época. Buendía afirma ainda que, através da análise de notas de tradução, é 
possível estabelecer relações que influenciem a recepção da tradução e a sua interpretação no sistema-alvo.

De uma forma geral, os diversos estudos sobre os paratextos de traduções têm mostrado que os enunciados presentes nos elementos paratextuais posicionam-se social e historicamente no interstício entre a linguagem como realizadora de significação e provedora de representações sígnicas e a realidade na qual ela se molda e é (re-) construída, formando assim variados tipos de discurso. Tais enunciados são proferidos por sujeitos que, vinculados às suas condições de produção, se inscrevem nos enunciados que proferem. Entre outros, é o que veremos no corpus da presente pesquisa que examinamos de forma diacrônica a seguir.

\section{Corpus da pesquisa: os paratextos}

O corpus da nossa pesquisa é composto por paratextos oriundos de onze traduções da peça Hamlet publicadas no Brasil em diferentes épocas. A tradução mais antiga que utilizamos foi publicada no Brasil em 1933 pela Schmidt Editora. Trata-se da primeira tradução da tragédia shakespeariana publicada no Brasil. A mais recente tradução do nosso corpus de pesquisa é a tradução de 2015 de Lawrence Flores Pereira, sendo também a última tradução nova efetivamente realizada. Em seguida, apresentamos os paratextos identificados em cada tradução publicada. A partir do corpus de onze traduções foram examinados cerca de trinta paratextos.

\section{A tradução de Tristão da Cunha (1933)}

Na tradução de Tristão da Cunha (Schmidt Editora, 1933), o primeiro detalhe que chama atenção é o uso do português seiscentista, com o objetivo de remeter à época da produção e publicação da peça shakespeariana. Esse aspecto não apenas é explorado na tradução em si como também no prefácio da obra, escrito pelo próprio Tristão da Cunha, o que parece apontar para o seguinte: o texto-fonte deve ser moldado de acordo com o seu contexto de produção e expressar o teor do texto-fonte de acordo com o período em que foi produzido. A folha de rosto informa que a tradução foi baseada no "texto de Cambridge". Ao longo do prefácio, podemos observar informações centrais sobre Shakespeare, que é tratado 
como um "gênio literário" de "incomparável magia de expressão". Traz à tona de forma breve e elegante a questão da autoria, lembrando que foram levantadas dúvidas em relação à veracidade de sua relação com as suas composições, muitas vezes atribuindo-lhes a outros autores como Francis Bacon. O mesmo prefácio enaltece a própria tradução, classificando-a como "honesta e simples", e argumenta que no ato de traduzir "muitas vezes é necessário sacrificar a palavra para não trair o espírito", construindo um diálogo com a ideia de que a tradução pode trair o texto-fonte caso determinados ajustes não sejam concretizados, e justifica que a tradução dos versos shakespearianos em forma de prosa evitou que o aspecto dramático da peça fosse prejudicado. Tristão da Cunha denomina a sua tradução como uma versão em "prosa poética", destacando que o ritmo do verso inglês se assemelha ao verso livre do simbolismo brasileiro, o que permitia e sustentava esse tipo de decisão tradutória. Por fim, alega que foi movimentado em sua tradução por um "pensamento estético", e não gramatical ou pedagogo.

\section{A tradução de Oliveira Ribeiro Neto (1948)}

A tradução de Oliveira Ribeiro Neto, por sua vez, apresenta apenas um texto promocional na orelha do livro e imagens que retratam o contexto de produção da peça shakespeariana, como a gravura do Swan Theatre, um dos primeiros teatros londrinos. O texto em questão enaltece o dramaturgo e a sua capacidade de adequar-se a qualquer contexto político e ideológico: "Até os regimes políticos respeitam Shakespeare, que é representado em todas as nações, seja qual for o seu regime ou ideologia" (s/p). Tal universalidade também se aplicaria aos movimentos literários diversos ao ressaltar que todas as 'escolas literárias' - "Dos românticos aos surrealistas" - prestam louvor ao 'Cisne de Avon', e que bebem em sua obra para elaborar suas teorias literárias, o que contribui para a "perenidade" e "indestrutibilidade" do seu cânone.

\section{A tradução de Silva Ramos (1965)}

Diferentemente da tradução anterior, a versão de Silva Ramos, publicada em 1955 pela Editora José Olympio, trata sobre a peça propriamente dita 
em seus paratextos. No primeiro texto prefacial, intitulado "Advertência", o único momento em que Silva Ramos aborda a peça é quando ressalta que é papel do tradutor não alhear-se à "prova do palco", devendo retocar o texto tendo a sua oralidade em mente, adaptando-se diante de edições, comentários e "o aproveitamento de frutos mais novos da erudição angloamericana" (p. 7). No texto seguinte, intitulado "Introdução" e também escrito por Silva Ramos, é fornecido o contexto sociohistórico da peça shakespeariana, com uma descrição sintética do antigo conto dinamarquês que continha o enredo original da trama: a narrativa do Livro III do Gesta Danorum, do Saxo Grammaticus. Além disso, também menciona a adaptação em prosa desta narrativa medieval na obra Histoires Tragiques de François Belleforest. Também não deixa de destacar a existência do Ur-Hamlet, suposta fonte diretamente utilizada por Shakespeare para a composição de sua peça. Silva Ramos não se aprofunda nas questões de tradução, atendose a situar, de forma breve, o leitor quanto à origem histórica da composição da peça. Embora não haja tal aprofundamento, apresenta 684 notas de rodapé sobre questões lexicais, de tradução e interpretação da peça.

\section{A tradução de Carlos Alberto Nunes (s/d)}

A versão de Carlos Alberto Nunes, publicada pela Ediouro, chama atenção pelo fato de não haver informações sobre as autorias dos dois textos prefaciais presentes. $\mathrm{O}$ primeiro texto parece ter sido confeccionado pela própria editora pela sua característica promocional, e o segundo texto se assemelha a um breve ensaio introdutório sobre a peça. $\mathrm{O}$ primeiro texto de apresentação, intitulado "Hamleto", aborda as fontes históricas da peça e faz uma breve sinopse do enredo. Além disso, tece algumas reflexões críticas sobre a obra, porém de modo genérico, sem de fato aprofundar-se nelas. Em meio a elogios enaltecedores ao que denomina como a "obraprima de Shakespeare", o autor do texto destaca que a peça seria uma "vasta carnificina sem interesse" se não fosse a "profunda respiração filosófica de Hamleto e o lirismo inefável de Ofélia" (p. 7).

No texto seguinte, intitulado "Prefácio", são repetidas as informações sobre as fontes, porém de forma mais detalhada e específica, 
além de reproduzir de forma mais profunda algumas ideias previamente dispostas no texto de apresentação, como a alusão à carnificina e o "príncipe pensador" como o agente da peça que traz sentido a ela, constituindo-se como a "alma da sede do conflito" que define a concepção artística da obra. As características peculiares e únicas de cada personagem, desse modo, formariam a relevância artístico-literária da peça. Ao fim da tradução, na posição de elemento pós-textual, um "Guia Universitário" escrito por Assis Brasil caracteriza a peça shakespeariana como "um dos mais expressivos monumentos literários que o homem já construiu" e Shakespeare como um "exímio autor de comédias, com ironia fina e o riso mordaz", cujas tragédias representam a "concepção trágica da vida".

\section{A tradução de Anna Amélia Carneiro de Mendonça (1995)}

A tradução de Anna Amélia Carneiro de Mendonça, publicada pela Editora Agir em 1968 e republicada no ano de 1995 pela Editora Nova Fronteira, apresenta paratextos mais extensos e detalhados em comparação aos descritos até o momento. A orelha de livro se encarrega de promover o livro na contracapa com um discurso de exaltação em torno do personagem de Hamlet, além de contextualizá-lo historicamente de forma breve. A sentença que resume o tom do texto trata a peça como "uma riqueza de experiências humanas que impossibilita qualquer resumo ou análise exaustiva" (s/p). Os dois prefácios escritos no livro são de autoria de Bárbara Heliodora e provêm de momentos distintos: o primeiro se refere à $1^{\text {a }}$ edição, de 1968 (referente à publicação da Editora Agir), em que Heliodora explica detalhadamente como o projeto dessa tradução fora inicialmente implementado. Também aborda outras questões como a dramaturgia elisabetana, mistura de tragédia e comédia, a "curiosidade do elisabetano", a oposição entre o Rei Hamlet, que representaria a era heroica medieval, e o Príncipe Hamlet, o homem moderno da Renascença e o tema de vingança tão popular naquela época.

No texto posterior, o prefácio à 2⿳a edição (Nova Fronteira, 1995), a utilizada para o presente estudo, se apresenta mais objetivo e curto. Heliodora aborda a questão envolvendo as fontes primárias da peça e a história das diferentes versões publicadas, a influência das tragédias de 
Sêneca em sua obra e discute brevemente o gênero tragédia de vingança, além de concluir com um comentário que dialoga com o aspecto da recepção de um texto literário: “É privilégio do leitor fazer a sua própria montagem imaginária e refazê-la, alterá-la, aprimorá-la, segundo as descobertas que irá fazendo a cada nova leitura desse texto inesgotável" (p. 23).

\section{A tradução de Cunha Medeiros e Oscar Mendes (1981)}

A tradução de Cunha Medeiros e Oscar Mendes, publicada primeiramente pela Nova Aguilar em 1969 e posteriormente republicada pela Editora Abril em 1981, contém um prefácio composto por uma "Sinopse" e pelos "Dados Históricos", escritos, conforme informado na própria obra, por Fernando Carlos de Almeida Cunha Medeiros. São paratextos mais sintéticos em relação aos anteriores, atendo-se a falar sobre a trama e aspectos históricos da obra. A "Sinopse" apresenta um resumo da peça, enquanto a seção "Dados Históricos" apresenta dois parágrafos em que são citadas as fontes históricas utilizadas por Shakespeare para a composição de Hamlet: "O mito de Hamlet é antiquíssimo na legenda escandinava" (p. 197). Além disso, fala brevemente sobre a desaparecida peça de Thomas Kyd e as versões da peça.

Nada se discute acerca do processo tradutório nos textos de apresentação, embora apresente cinquenta notas explicativas que esclarecem determinadas alusões para o leitor e elucidam alguns termos não muito conhecidos e alguns trocadilhos específicos. Trata-se da segunda tradução a possuir tal característica depois da versão de Silva Ramos.

\section{A tradução de Geraldo Silos (1984)}

A tradução de Geraldo Silos, publicada pela Editora JB em 1984, por sua vez, apresenta conteúdo paratextual extenso. Os dois textos nele presentes, intitulados, respectivamente, "Prefácio" e "Introdução", foram escritos pelo tradutor. No primeiro texto, mais curto, Silos fala diretamente do processo tradutório, citando os cinco anos de pesquisa na Biblioteca Nacional do Canadá, além de fornecer comentários sobre aspectos gramaticais da tradução, como a alternância entre pronomes pessoais tu e vós para 
expressar diferentes situações nas cenas, atestando que seguiu rigorosamente o texto original. Afirma que a gramática de Shakespeare na tradução pode "chocar o leitor", porém é "perfeitamente aceitável" para o espectador de teatro, pois a mudança de comportamento do personagem fica mais visível com os gestos, o tom e a expressão do ator. Ainda recomenda o leitor, de forma indireta, a comparar o texto traduzido com o texto fonte.

Como de praxe em diversos paratextos até aqui pesquisados, Silos recapitula historicamente as fontes exploradas pelo Bardo para a composição de sua peça. Contudo, afirma quase categoricamente que Shakespeare utilizou o texto de Kyd, o "Ur-Hamlet", este, por sua vez, baseado na obra original de Belleforest. Inclusive, esta edição reproduz a página de rosto e a primeira página do Gesta Danorum, ou História Dânica, de Saxo Grammaticus.

\section{A tradução de Millôr Fernandes (1988)}

A tradução de Millôr Fernandes não apresenta um extenso número de elementos paratextuais. O prefácio, ou introdução, sem atribuição de autoria, intitulado "William Shakespeare (1564-1616)", traz uma série de informações biográficas sobre o bardo, o panorama histórico das peças por ele escritas e uma breve contextualização histórica de sua época. Destaque para o parágrafo que trata dos teatros elisabetanos, a segunda menção feita a esta questão (a primeira foi na tradução de Anna Amélia, no prefácio de Heliodora), falando de aspectos como a sacada típica presente neste tipo de palco e a intensa interação advinda da proximidade física dos atores com o público. Na conclusão do texto, diz que suas peças se destacam pela "grandeza poética da linguagem, pela profundidade filosófica e pela complexa caracterização dos personagens" e arremata com a afirmação de que se trata "unanimemente um dos mais importantes autores de todos os tempos". Como se pode observar, trata-se de um prefácio que não aborda a peça nem a sua tradução, tratando Shakespeare, sua obra e sua época de forma genérica, sem fornecer informações adicionais.

$\mathrm{Na}$ contracapa, um breve texto editorial que serve como apresentação inicial da obra, promove a peça Hamlet como uma obra que 
trata da condição humana, da vingança e questões como dúvida e desespero, todos expressos nos monólogos do personagem principal, compondo o que o texto denomina como uma "dimensão trágica". Em seguida, realça a tradução realizada por Millôr Fernandes, destacando o seu posicionamento crítico contra uma visão erudita que prejudicaria o texto dramático ao verter para a língua de chegada. A proposta da tradução de Millôr, conforme tal paratexto, seria tornar o texto da peça compreensível em português sem prejudicar a sua dramaticidade.

\section{A tradução de Elvio Funck (2005)}

A tradução de Elvio Funck, pela Editora Unisinos, contém o paratexto que mais aborda o processo tradutório dentre todos encontrados até o momento, sendo a primeira tradução da peça realizada diretamente por um estudioso acadêmico do autor. No parágrafo inicial do texto de introdução, destaca a produção acadêmica em torno do cânone dramático de Shakespeare e se pergunta o porquê de tantas atenções atribuídas para a obra do autor, procurando dialogar com o leitor. Caracteriza Shakespeare como o "autor sobre o qual mais se escreve no mundo" e o classifica como um "profundo conhecedor da natureza humana", alegando que muitas de suas considerações sobre o homem escapam ao que ele denomina como 'leitor comum'. Critica de forma indireta todas as traduções já feitas de Hamlet, resumindo cada uma como "uma narrativa linear e superficial do enredo" (p. 7). A tradução interlinear, conforme justifica em seguida, seria uma tentativa de agradar aqueles que não manejam bem o inglês ou que gostam de comparar as duas línguas. E esclarece que fez essa tradução originalmente pensando nos alunos de graduação dos cursos de Licenciatura: "parâmetro que modulou não somente o tom da tradução propriamente dita, mas também o dos comentários" (p. 8).

Quanto às notas explicativas, explica que são necessárias para compreender determinadas passagens nas peças shakespearianas. Distingue os leitores que apenas se interessam pelo enredo da peça, os quais, segundo ele, devem ler traduções que privilegiam a narrativa linear em prosa, dos "verdadeiros leitores", que devem ler a obra com o "maior amparo crítico-histórico possível". Tece uma autocrítica em relação ao seu 
próprio trabalho com a afirmação de que as notas podem ser muito longas ou com "tom de sala de aula", mas são necessárias para uma leitura mais proveitosa da peça em questão. Em seguida, contextualiza historicamente a obra, rememorando a situação da Inglaterra em fins do período elisabetano. Menciona o Ur-Hamlet sem citar a suposta autoria de Thomas Kyd e menciona também Saxo Grammaticus e a sua Historiae Danicae. Por fim, cita alguns críticos literários e escritores conhecidos que tentaram interpretar e compreender Hamlet em sua plenitude: Samuel Johnson, Goethe, Coleridge, Eliot e Bradley e suas respectivas visões distintas acerca da obra.

\section{A tradução de José Roberto O'Shea (2010)}

$\mathrm{Na}$ versão de O'Shea (Hedra, 2010), os paratextos são relativamente extensos e recheados de conteúdo relevante. Nas páginas que antecedem o sumário, tem-se um resumo biográfico de William Shakespeare, oferecendo informações a respeito de sua origem familiar e destacando que as fontes biográficas são oriundas de registros da época e alusões de contemporâneos. Em seguida, um texto prefacial intitulado Introdução, escrito pelo próprio tradutor, trata do Primeiro Hamlet, destaca que a diferença entre as três versões reside na extensão, estrutura e caracterização e nomes dos personagens, e às rubricas; enumera as diferenças entre elas; destaca que a primeira versão teria sido utilizada na primeira encenação; e finaliza com uma síntese biográfica do tradutor, destacando que se trata de um professor com extensa pesquisa nos estudos literários de um modo geral. Descreve a história da publicação das versões e ressalta que a primeira versão publicada da peça enfatiza mais a ação que a introspecção. Nas subseções que seguem, o tradutor trata das hipóteses da produção desta versão; enfatiza as suas qualidades dramáticas; enumera as diferenças entre as versões mais conhecidas; e, por fim, traça um panorama das performances realizadas no Brasil com base nesta versão da peça e também em toda a Europa, incluindo apresentações contemporâneas.

\section{A tradução de Lawrence Flores Pereira (2015)}

Na tradução mais recente, de Lawrence Flores Pereira, deparamo-nos com quatro textos prefaciais na seguinte ordem: a Introdução escrita pelo 
tradutor, o ensaio Hamlet e seus problemas de T. S. Eliot, traduzido pelo próprio Flores Pereira, e depois dois textos - Nota sobre o texto e Nota sobre a tradução. Após a tradução, temos as notas explicativas. As questões abordadas por Lawrence no texto introdutório são regidas pelos seguintes temas: fontes da peça, trazendo uma abordagem mais detalhada a respeito do "Ur-Hamlet" e discutindo as alterações feitas por Shakespeare a partir do enredo original. Enfatiza o sucesso das tragédias de vingança, a qual justifica com o perfil do público londrino da época, que realizaria "desejos vendetistas secretos" (p. 13).

Em seguida, ecoa a visão de Eliot de que Shakespeare tentou fundir a tragédia de vingança com as reflexões poéticas de seus sonetos, levando a um "fracasso dramático". Cita visões críticas de diversos estudiosos e escritores. Traz a visão de Goethe sobre o personagem, que o classifica como um "jovem 'nobre', porém desprovido da fibra para cumprir deveres como aquele que o fantasma lhe impõe" (p. 21). Menciona também a visão de Coleridge, que o vê como um homem muito ligado ao hábito do pensamento, sem capacidade de agir. Em seguida, tece diversos comentários sobre a teatralidade da obra, aspecto pouco aprofundado nos paratextos de outras traduções.

No ensaio de Eliot que se segue ao texto, temos uma crítica dura ao enredo da peça, na qual se realça a importância de trazer ao leitor da obra de arte a apresentação de fatos históricos relevantes. Eliot denomina a peça como um "fracasso artístico", com "cenas supérfluas e inconsistentes que até uma revisão apressada teria apontado", e ressalta a dificuldade de localizar os sentimentos em Hamlet assim como ocorre nos sonetos shakespearianos.

Na Nota sobre o texto, Lawrence apresenta o panorama histórico das versões das peças, explicando fundamentalmente que utilizou como base o Q2 e mais 85 linhas do Fólio. Na Nota sobre a tradução, finalmente aborda a questão tradutória: busca as ideias de Haroldo de Campos sobre tradução de poesia para falar a respeito, citando o termo haroldiano "Transluciferação mefistofélica" para falar sobre o início de seu trabalho como tradutor de Hamlet; realça a importância de traduzir a tonalidade idiomática das falas e a retórica da época, e também de reproduzir as 
piadas e os trocadilhos para provocar o mesmo efeito na enunciação teatral. Trata ainda da questão do verso: segundo o próprio tradutor, o pentâmetro iâmbico das passagens em verso da peça é transposto para o verso dodecassílabo, para evitar uma ritmação excessivamente audível e também que palavras tenham que ser cortadas. Finaliza com a seguinte afirmação sobre a sua tradução: "Busquei a riqueza vocabular, o uso cuidadoso de inversões, as modulações poéticas capazes de produzir efeitos singulares, o uso de pronomes variados para assinalar registros, os termos médicos e alquímicos e tantas outras peculiaridades" (p. 46).

\section{Discursos presentes nos paratextos: uma proposta de categorização}

A análise paratextual delineada na seção anterior demonstrou a ocorrência de determinados padrões discursivos: a ideologia de tradução; o discurso sobre a tradução; o discurso promocional; o discurso sobre o autor; o discurso sobre a obra. Esses cinco diferentes tipos discursivos se expressam de diferentes modos nos paratextos, e por vezes ocorrem simultaneamente no mesmo elemento paratextual. A tabela abaixo indica em que traduções tais discursos surgem:

\begin{tabular}{|l|l|l|l|l|l|}
\hline Tradução & $\begin{array}{l}\text { Ideologia } \\
\text { de } \\
\text { tradução }\end{array}$ & $\begin{array}{l}\text { Discurso } \\
\text { sobre a } \\
\text { tradução }\end{array}$ & $\begin{array}{l}\text { Discurso } \\
\text { promocional }\end{array}$ & $\begin{array}{l}\text { Discurso } \\
\text { sobre } \\
\text { autor }\end{array}$ & $\begin{array}{l}\text { Discurso } \\
\text { sobre a } \\
\text { obra }\end{array}$ \\
\hline Tristão da Cunha & $\mathrm{X}$ & $\mathrm{X}$ & $\mathrm{X}$ & $\mathrm{X}$ \\
\hline $\begin{array}{l}\text { Oliveira Ribeiro } \\
\text { Neto }\end{array}$ & $\mathrm{X}$ & $\mathrm{X}$ & $\mathrm{X}$ & $\mathrm{X}$ & $\mathrm{X}$ \\
\hline $\begin{array}{l}\text { Péricles Eugênio } \\
\text { da Silva Ramos }\end{array}$ & & & $\mathrm{X}$ & $\mathrm{X}$ & $\mathrm{X}$ \\
\hline $\begin{array}{l}\text { Carlos Alberto } \\
\text { Nunes }\end{array}$ & $\mathrm{X}$ & $\mathrm{X}$ & $\mathrm{X}$ & $\mathrm{X}$ & $\mathrm{X}$ \\
\hline $\begin{array}{l}\text { Anna Amélia de } \\
\text { Mendonça }\end{array}$ & & & & $\mathrm{X}$ & $\mathrm{X}$ \\
\hline $\begin{array}{l}\text { Cunha Medeiros } \\
\text { \& Oscar Mendes }\end{array}$ & & & & & \\
\hline
\end{tabular}




\begin{tabular}{|l|r|r|r|r|r|}
\hline Geraldo Silos & $X$ & $X$ & $X$ & $X$ & $X$ \\
\hline Millôr Fernandes & $X$ & $X$ & $X$ & $X$ & $X$ \\
\hline Elvio Funck & & & & $X$ & $X$ \\
\hline $\begin{array}{l}\text { José Roberto } \\
\text { O'Shea }\end{array}$ & $X$ & $X$ & & $X$ & $X$ \\
\hline $\begin{array}{l}\text { Lawrence Flores } \\
\text { Pereira }\end{array}$
\end{tabular}

Tabela 1. Tipos de discurso presentes nos paratextos das traduções de Hamlet

A partir da categorização apresentada na Tabela 1, é possível comentar criticamente os possíveis fatores sociais, históricos e culturais que induziram tais tipos de discurso, mas antes é preciso definir esses tipos de discurso.

Dois tipos discursivos possuem relação direta com o processo tradutório: a ideologia de tradução e o discurso sobre a tradução. "Ideologia de tradução" consiste na visão sobre a tradução de um modo mais amplo, tendo relação direta com as estratégias tradutórias e com a forma como a tradução é apresentada ao público leitor. Trata-se, em suma, da apresentação de um modelo ideal para a realização do processo tradutório. O "discurso sobre a tradução", por sua vez, possui um caráter mais específico e se relaciona de forma mais direta com a prática tradutória: consiste na descrição feita sobre a própria tradução, uma análise crítica do processo tradutório. Ainda que muitas vezes se encontrem no mesmo plano sintático no paratexto, configuram-se como discursos distintos devido a seus objetivos e características específicas. No prefácio de Tristão da Cunha, por exemplo, o tradutor deixa evidente a sua visão sobre tradução ao tratar do "sacrifício da palavra para não trair o espírito". Ao mesmo tempo, discursa sobre a sua tradução ao justificar a escolha do formato de prosa para a tradução dos versos da peça. Aspectos relacionados a essa tipologia surgem de forma pouco aprofundada nas 
versões de Silva Ramos (1955) e Anna Amélia de Mendonça (1968). A tradução de Geraldo Silos (1984), com a introdução e o prefácio de autoria do próprio tradutor, apresenta os dois aspectos de forma mais detalhada. Funck (2005) não apresenta apenas a sua visão sobre tradução, como tece um discurso sobre a sua, justificando o seu projeto de tradução linear. A versão de Pereira (2015) apresenta o texto "Nota sobre a tradução" entre seus paratextos, demonstrando evidente preocupação em tratar sobre tal aspecto. É notório que esses aspectos tenham surgido de forma mais detalhada nas traduções mais recentes, ainda que não exerçam o discurso predominante no paratexto. Apesar de ter adquirido mais notoriedade nas últimas décadas, a voz do tradutor a respeito de sua prática e de seu trabalho ainda é invisível nos paratextos.

O "discurso promocional" é outro conceito chave aqui elaborado para compreender os enunciados presentes nos paratextos. Trata-se do discurso que representa a voz da editora, do agente cultural (LEFEVERE, 1992) responsável por promover a reescrita da obra em questão. Pode surgir de forma mais explícita em alguns paratextos, como no caso de textos contidos na orelha do livro, tal qual a tradução de Oliveira Ribeiro Neto e também na de Anna Amélia de Mendonça. Na tradução de Millôr, o discurso promocional é evidente na contracapa, e promove não apenas a obra e o autor, como também a figura do próprio tradutor. A voz da editora também surge de forma sutil no interior de outros padrões discursivos, como nos discursos sobre o autor e a obra contidos em alguns paratextos que enaltecem a peça e o Bardo.

O "discurso sobre a obra" e o "discurso sobre o autor" são padrões de imediata percepção, possuindo clara predominância no discurso paratextual das traduções de Hamlet como um todo. O discurso sobre a obra se realizou de variadas maneiras: informações factuais a respeito do texto-fonte, como as fontes históricas do enredo da peça, a história das três versões; o contexto de produção da peça, mais precisamente a história do teatro elisabetano, além da história da recepção da obra shakespeariana; apresentação de aspectos críticos relacionados à obra, seja de um modo geral, seja sob um recorte bem específico, de forma autoral ou citando outros pesquisadores que discorreram a respeito da obra em questão. $\mathrm{O}$ 
"discurso sobre o autor", por sua vez, se caracteriza por apresentar uma descrição biográfica, ora resumida, ora mais aprofundada, do dramaturgo e relacionar a sua figura ao contexto em que ele se encontrava, de modo a fazer comentários breves ou críticos sobre como aspectos externos à sua composição influenciaram para a formação de seu cânone. Ambos os discursos se encontram imbricados um no outro em diversos momentos nos paratextos analisados. Todas as traduções da peça apresentam esses tipos de discurso, o que nos transmite a impressão de uma necessidade contínua de apresentar o dramaturgo, a sua obra e sua época para o público leitor, especializado ou não.

Através destes tipos discursivos, é possível traçar dois principais tipos de paratexto: o paratexto sobre tradução e o paratexto de apresentação. $O$ paratexto sobre tradução, como o próprio nome diz, se configura como aquele que discursa sobre o processo tradutório nas mais variadas esferas. Apresenta de forma predominante o discurso sobre a tradução ou a ideologia de tradução, ou ambos os tipos no mesmo plano discursivo. A sua presença na obra traduzida transfere uma necessidade, em maior ou menor grau, de tratar da tradução realizada. Com o papel do tradutor adquirindo maior importância no meio acadêmico e literário, ainda que de forma um tanto incipiente, esse paratexto tende a ganhar mais corpo, como se pode notar nas traduções mais recentes.

O paratexto de apresentação, no entanto, ainda se constitui como o mais proeminente nas traduções da peça. Tal paratexto, como se pode observar, possui diversas vertentes: pode predominar o discurso sobre o autor ou sobre a obra, ou em ambos de forma equivalente. Pode explorar as questões a eles relacionadas de forma meramente didática, ou pode simplesmente servir para apenas promover e enaltecer para o leitor, o que em geral se expressa através do discurso promocional. A sua predominância nos leva a crer que a necessidade de apresentar a obra shakespeariana não se esgota, apresentando-se em todas as traduções. As três últimas traduções deixam evidente essa característica, a qual também se coaduna com o fato de terem sido produzidas por pesquisadores especialistas no Bardo. 
Pudemos observar, a partir da análise diacrônica realizada acima, a forma como os paratextos foram se moldando e se articulando ao longo da história das traduções da peça Hamlet no Brasil. Ainda que os enunciados que formam o discurso tenham se alterado de acordo com o seu contexto social e histórico, o padrão temático em torno da necessidade de apresentar e introduzir a obra literária no paratexto de tradução manteve-se constante, apenas alternando a forma de se constituir tal discurso - enaltecendo de forma genérica, trazendo aparato crítico, destacando aspectos históricos e biográficos, dentre outras formas de apresentação. Ao mesmo tempo, também podemos deduzir uma determinada visão sobre tradução que foi se alterando no passar das décadas, mas que ainda se encontra de forma muito precária nos paratextos, mesmo que já tenha adquirido determinado espaço neste limiar entre o livro e o público. Podemos incluir nessa discussão a questão da invisibilidade do tradutor, que ainda se faz bem presente nos paratextos, não obstante as mudanças apresentadas nas últimas traduções visando uma maior importância crítica a questões de tradução. Ambos os aspectos - a visão sobre tradução e a visão em torno da obra e do autor - nos parecem, portanto, constituir os dados mais proeminentes dos paratextos aqui analisados, traçando os conceitos de tradução e recepção como os dois principais enfoques contidos nos discursos dos paratextos.

\section{Considerações finais}

A análise aqui empreendida buscou observar a obra traduzida sob o viés de sua recepção através dos paratextos. Utilizando-se do paradigma descritivista, o foco se voltou a aspectos externos relacionados ao texto traduzido com o pressuposto de observar o texto traduzido como um elemento construído pelo seu momento social e histórico. O paratexto é parte integrante da obra, e estudá-lo também significa traçar um panorama histórico e contextual a respeito do texto traduzido. A relação do estudo do paratexto com o estudo de recepção da obra também se faz evidente, uma vez que a função paratextual perpassa pela mediação entre a obra literária e o público leitor. 
No caso do texto traduzido, como nos foi possível observar, essa mediação se realiza por meio de dois enfoques centrais: a visão sobre o aspecto ideológico e prático do processo tradutório; e a apresentação da obra literária em caráter didático e/ou promocional, influenciando em sua recepção. Os resultados da pesquisa apontam para um maior interesse por parte do leitor em conhecer o processo tradutório. Há dois tipos de dados na nossa pesquisa que apoiam essa constatação. Por um lado, verificou-se um aumento nesse tipo de informação ao longo das décadas e, por outro, os tradutores de Hamlet na atualidade são professores e pesquisadores que tendem a fundamentar as decisões que tomaram em seus textos. Esses dois fatores estão provavelmente ligados ao desenvolvimento dos Estudos de Tradução como área acadêmica no período temporal que cobrimos nesta pesquisa, pois com esse desenvolvimento surgiram especialistas em tradução, um aumento no número de traduções numa escala global e uma maior visibilidade dos tradutores. Assim, o horizonte de expectativas do leitor de uma tradução de Hamlet parece incluir cada vez mais a noção de que a obra de um autor canônico, como Shakespeare, exige uma reescrita frequentemente baseada em pesquisa acadêmica.

Outros trabalhos que mencionamos aqui mais cedo também buscaram estudar o paratexto com o fim de entender algum ponto da recepção da obra, como compreender as normas literárias de um determinado período histórico; analisar como determinado texto é compreendido na cultura do sistema-alvo; e relacionar as estratégias tradutórias apresentadas no paratexto com a prática tradutória em si. O objetivo aqui proposto, portanto, foi categorizar os discursos presentes no paratexto para entender a relação entre a obra literária e a cultura em que ela se encontra imersa por meio de padrões que pudemos identificar. Seria, no entanto, relevante desenvolver mais pesquisas deste gênero para cruzar dados sobre o paratexto de tradução literária.

\section{Referências}

BUENDÍA, C. T. Listening to the voice of the translator: A description of translator's notes as paratextual elements. The International Journal for Translation and Interpreting Research, v. 5, n. 2, 2013. p. 149-62. 
EVEN-ZOHAR, I. The Position of Translated Literature Within the Literary System. In: VENUTI, Lawrence. (Org.) The Translation Studies Reader. London: Routledge, 2000. p. 192-197.

GENETTE, Gerárd. Paratexts: Thresholds of Interpretation. Translated by Jane E. Lewin. Cambridge: Cambridge University Press, 1997.

TAHIR-GÜRÇAGLAR, S. Paratexts. In: Handbook of Translation Studies. Edited by Yves Gambier and Luc van Doorslaer. Amsterdam/Philadelphia: John Benjamins Publishing Company, 2011. p. 113-16.

ISER, W. The Act of Reading: A Theory of Aesthetic Response. Baltimore and London: The John Hopkins University Press, 1978.

JAUSS, H. R. (1967). Literary History as a Challenge to Literary Theory. In: Towards an Aesthetic of Reception. Translated by Tymothy Bahti. Minneapolis: University of Minnesota Press, 1982.

LEFEVERE, André. Translation, Rewriting, and the Manipulation of Literary Fame. London and New York: Routledge, 1992.

MARTINS, M. A. P. A voz dos tradutores shakespearianos em seus paratextos. TradTerm, São Paulo, v. 26, Dez. 2015. p. 87-120.

PELLATT, V. Introduction. In: Text, Extratext, Metatext and

Paratext in Translation. Cambridge: Cambridge Scholars Publishing, 2013, p. 1-6.

SHAKESPEARE, William. A Tragédia de Hamlet, Príncipe da Dinamarca. Tradução, introdução e notas de Péricles Eugênio da Silva Ramos. São Paulo: Conselho Estadual de Cultura, 1965.

Hamleto, Príncipe da Dinamarca. Trad. Carlos Alberto Nunes. São Paulo: Ediouro, s/d.

Hamlet e Macbeth. Tradução de Hamlet por Anna Amélia Carneiro de Mendonça; tradução de Macbeth por Bárbara Heliodora. Rio de Janeiro: Nova Fronteira, 1995.

Hamlet. Tradução, introdução e notas de Geraldo de Carvalho Silos. Rio de Janeiro: Editora JB, 1984.

Hamlet. Trad. Millôr Fernandes. Porto Alegre: LP\&M, 2012.

Hamlet. Tradução interlinear e notas de Elvio Funck. São Leopoldo:

Unisinos, 2005. 
Hamlet, príncipe da Dinamarca. Tradução, introdução e notas de Lawrence Flores Pereira. São Paulo: Penguin Classics Companhia das Letras, 2015.

O primeiro Hamlet: In-quarto de 1603. Organização e tradução de José Roberto O'Shea. São Paulo: Hedra, 2010.

Romeu e Julieta; Macbeth; Hamlet, Príncipe da Dinamarca; Otelo, o Mouro de Veneza. Trad. F. Carlos de Almeida Cunha Medeiros e Oscar Mendes. São Paulo: Abril Cultural, 1981.

A Tragédia de Hamleto, Príncipe da Dinamarca. Trad. Tristão da Cunha. Rio de Janeiro: Schmidt, 1933.

Tragédias de Shakespeare: Romeu e Julieta, Hamlet e Macbeth. Trad. Oliveira Ribeiro Neto. São Paulo: Martins Editora, 1960.

TOURY, G. The Nature and Role of Norms in Translation. In: VENUTI, L. (Org.) The Translation Studies Reader. London: Routledge, 2000. p. 198211.

\section{Resumo}

A presente pesquisa analisa os paratextos de onze traduções de Hamlet publicadas no Brasil entre 1933 e 2015 . Cerca de trinta paratextos foram examinados e determinados padrões discursivos foram identificados nos enunciados paratextuais. A pesquisa mostrou que, ainda que os enunciados tenham se alterado de acordo com o seu contexto social e histórico, o padrão discursivo em torno da necessidade de apresentar e introduzir a obra literária no paratexto de tradução manteve-se constante. Ao mesmo tempo, a pesquisa também mostrou uma mudança na ideologia e nos discursos sobre a tradução no passar das décadas, sendo prova disso o maior espaço dado ao paratexto de tradução atualmente.

Palavras-chave: Shakespeare; Hamlet; paratexto; discurso; diacronia.

\section{Abstract}

The paper analyzes the paratexts of eleven translations of Hamlet that were published in Brazil between 1933 and 2015. About thirty paratexts were examined and certain discursive patterns were identified. Our research has shown that, although the content of the paratexts has changed according to 
the social and historic contexts of their production, there is a recurring discursive pattern about the need to present and introduce the literary work to the target public. At the same time, the research has also shown that the there was a change in the ideology and in the discourse about translation throughout the last decades, which is demonstrated by a greater use of paratexts about the translation.

Keywords: Shakespeare; Hamlet; paratexts; discourse; diachronic study 